\title{
Brazilian Journal of Chemical

\section{EFFECT OF AMMONIA LOAD ON EFFICIENCY OF NITROGEN REMOVAL IN AN SBBR WITH LIQUID-PHASE CIRCULATION}

\author{
C. S. A. Canto ${ }^{1}$, S. M. Ratusznei ${ }^{1}$, J. A. D. Rodrigues ${ }^{1 *}$, M. Zaiat $^{2}$ and E. Foresti $^{2}$ \\ ${ }^{1}$ Escola de Engenharia Mauá, Instituto Mauá de Tecnologia (EEM-IMT), Praça Mauá 1, \\ CEP: 09580-900, São Caetano do Sul - SP, Brazil. \\ E-mail: rodrigues@maua.br \\ ${ }^{2}$ Departamento de Hidráulica e Saneamento, Escola de Engenharia de São Carlos, Universidade de São Paulo \\ (EESC-USP), Av. Trabalhador São-Carlense 400, CEP: 13566-590, São Carlos - SP, Brazil.
}

(Received: August 14, 2006 ; Accepted: January 14, 2007)

\begin{abstract}
The removal of biological nitrogen from a synthetic wastewater with different ammonium nitrogen concentrations (50 and $100 \mathrm{mgN}-\mathrm{NH}_{4}{ }^{+} / \mathrm{L}$ ) by a nitrification and denitrification process using a sequencing batch biofilm reactor (SBBR) with liquid-phase circulation was studied. The system with a total working volume of $4.6 \mathrm{~L}(3.7 \mathrm{~L}$ in the reactor and $0.9 \mathrm{~L}$ in the reservoir) treated $2.1 \mathrm{~L}$ of synthetic wastewater in $12-\mathrm{h}$ cycles. As inoculum two types of biomass were used: an anaerobic/anoxic one from an up-flow anaerobic sludge blanket reactor (UASB) and an aerobic one from a prolonged aeration activated sludge system. The system, maintained at $30 \pm 1{ }^{\circ} \mathrm{C}$, operated in batch mode followed by fed-batch mode and was aerated intermittently. During fed-batch operation the reactor was fed with an external carbon source as electron donor in the denitrifying step and with no aeration. When the reactor was fed with $50 \mathrm{mgN}-\mathrm{NH}_{4}{ }^{+} / \mathrm{L}$, efficiencies of removal of ammonium nitrogen and total nitrogen from the effluent were 93.8 and $72.2 \%$, respectively, and nitrite, nitrate and organic nitrogen concentrations were $0.07,6.4$ and $0.5 \mathrm{mg} / \mathrm{L}$, respectively. On the other hand, when the influent ammonium nitrogen concentration was $100 \mathrm{mgN}-\mathrm{NH}_{4}^{+} / \mathrm{L}$, residual nitrite and nitrate were 0.17 and 20.4, respectively, and no N-Org was found in the effluent. It should be mentioned that residual nitrate remained unaltered at the different $\mathrm{C} / \mathrm{N}$ ratios used. Consequently, efficiency of total nitrogen removal was reduced to $66.7 \%$, despite efficiency of ammonium nitrogen removal exceeding $90 \%$. These results show the potential of the proposed system in removing ammonium nitrogen from liquid effluents with a moderate ammonium nitrogen concentration.

Keywords: Nitrification and denitrification; Immobilized biomass; Sequencing batch biofilm reactor; Liquidphase circulation.
\end{abstract}

\section{INTRODUCTION}

The main sources of nitrogen emission include application of manurial nitrogen in excess of crop needs and intensive confined animal breeding. However, industrial effluents, particularly of industries located in small and medium-sized communities, also play an important role in this process (Bilanovic et al., 1999). These effluents jeopardize the water quality of many aquifers and may cause serious eutrophication in waterways and increase population health problems related to the intake of nitrogen in certain forms (Bilanovic et al., 1999; Peng et al., 2004). The treatment of liquid effluents containing ammonium nitrogen has, therefore, attracted the attention of many investigators during the last decade.

Nitrification and denitrification are the most widely used large-scale biological processes for organic and ammonium nitrogen removal from 
wastewaters. Nitrification takes place by autotrophic aerobic means (i.e., low carbon source concentrations), which oxidize ammonium nitrogen to nitrite and subsequently to nitrate. Denitrification occurs under heterotrophic anoxic conditions, where organic carbon sources act as electron donors and reduce nitrate to nitrogen gas.

A large number of system configurations have utilized biological nitrification and denitrification processes with considerable success. The sequencing batch reactor (SBR) in particular has been shown to be extremely flexible for these kinds of processes because it allows the use of sequencing anaerobic, anoxic, and aerobic zones and is relatively inexpensive and very effective in treating systems for small to medium-sized communities. Moreover, it is able to produce the conditions required for biological nitrogen removal by simply modifying application and duration of mixing and aeration (Louzeiro et al., 2002; Aulenta et al., 2003; Linlin et al., 2005; Obaja et al., 2005).

A critical factor in ammonium nitrogen removal is the requirement of oxygen for the nitrification process. An immobilized biomass system (biofilm) appears to be advantageous due to reduced energy costs for aeration. When a biofilm is adapted to an $\mathrm{SBR}$, the reactor becomes an SBBR, i.e., sequencing batch biofilm reactor.

Some SBBR configurations still incorporate recirculation of the generated liquid and/or gaseous effluent into the reactor itself to improve both mixing and contact between biomass and wastewater as well as to dilute the influent in the case of high-strength wastewaters. Another, equally important factor is the mass transfer occurring in two distinct phases: (a) inside the reactor, from the liquid medium to the biofilm surface, and (b) inside the biofilm after contact with its surface. Hence, SBBR with liquidphase recirculation seems to be a promising alternative in treating conventional nitrogen wastewaters (Metcalf and Eddy Inc., 2003).

The scope of this investigation was to use the advantages of the SBBR, with liquid-phase circulation in the post-treatment of liquid effluents containing ammonium nitrogen by conventional nitrification and denitrification processes. In particular, the behavior of this type of reactor was evaluated when submitted to two different influent concentrations, denominated low and moderate (50 and $100 \mathrm{mg} / \mathrm{L}$, respectively), while maintaining some operational conditions (cycle length, temperature, influent composition, recirculation flow rate) and optimizing others $(\mathrm{C} / \mathrm{N}$, ratio, feed time, aeration time) in order to understand the relation between the influent ammonium nitrogen concentrations, the operational conditions and consequent removal efficiencies. Moreover, a better insight into the behavior of this system was sought for future scaleup applications.

\section{MATERIALS AND METHODS}

\section{Biomass}

Two types of biomass were used, an anaerobic/anoxic one from a UASB and an aerobic one from a prolonged aeration activated sludge system (Canto et al., 2004 and 2007). The biomass used in the reactor was immobilized on an inert support consisting of $1.0-\mathrm{cm}$ polyurethane foam cubes, according to a methodology developed by Zaiat et al. (1994).

\section{Synthetic Wastewaters}

Two types of synthetic wastewaters were used. The first one (denominated "synthetic wastewater I" or SW), fed in the batch stage at a concentration of around $100 \mathrm{mgCOD} / \mathrm{L}$, was prepared with sucrose (7 $\mathrm{mg} / \mathrm{L})$, starch $(22.8 \mathrm{mg} / \mathrm{L})$, cellulose $(6.8 \mathrm{mg} / \mathrm{L})$, meat extract $(41.6 \mathrm{mg} / \mathrm{L})$, soybean oil $(10.2 \mathrm{mg} / \mathrm{L})$, $\mathrm{NaCl} \quad(50 \mathrm{mg} / \mathrm{L}), \quad \mathrm{MgCl}_{2} \cdot 6 \mathrm{H}_{2} \mathrm{O} \quad(1.4 \mathrm{mg} / \mathrm{L})$, $\mathrm{CaCl}_{2} \cdot 2 \mathrm{H}_{2} \mathrm{O} \quad(0.9 \mathrm{mg} / \mathrm{L}), \mathrm{NaHCO}_{3}$ (initially 500 $\mathrm{mg} / \mathrm{L})$, commercial detergent for soybean oil emulsification ( 3 drops/L) and $\mathrm{NH}_{4} \mathrm{Cl}$ as ammonium nitrogen source. This synthetic wastewater was formulated to simulate the effluent of an anaerobic reactor. Its composition in terms of carbohydrates, proteins and lipids is similar to that of a domestic wastewater (Souza and Foresti, 1996). With regard to the ammonium concentration, levels used varied between medium and high strength (50 and 100 $\mathrm{mg} / \mathrm{L}$ ), as suggested by Metcalf and Eddy (2003, p. 186) for untreated domestic wastewater.

The substrate (without nitrogen source) was sterilized $\left(121^{\circ} \mathrm{C}, 15 \mathrm{~min}\right)$ to maintain the original physicochemical properties of the synthetic wastewater and prevent natural degradation due to contamination by microorganisms during the assays, and consequently minimize the effect of this factor on the results. It should be mentioned that sterilization did not alter the original characteristics of the influent and that this approach is frequently used in research with bench-scale reactors in order to focus on the manipulated variables and consequently obtain knowledge of the process in a "fundamental" way. Although not viable as a full-scale process, this 
approach is very useful in lab-scale studies. The modifications mentioned as "not occurring" were related to those detected by physicochemical analysis as COD, alkalinity, total volatile acids and solids. Other changes, such as hydrolysis of the polymeric compounds, are likely minimal and were not taken into account due to the low concentration levels of these compounds (from 7 to $42 \mathrm{mg} / \mathrm{L}$ ).

Two influent ammonium concentrations were analyzed: 50 (condition 1) and $100 \mathrm{mgN}^{-\mathrm{NH}_{4}}{ }^{+} / \mathrm{L}$ (condition 2), and $\mathrm{NH}_{4} \mathrm{Cl}$ concentrations were about 195.6 and $391.2 \mathrm{mg} / \mathrm{L}$, respectively. Under both conditions concentrations of the remaining components were maintained. It should be mentioned that $\mathrm{NH}_{4} \mathrm{Cl}$ ("synthetic wastewater I") was only added when reactor feeding was batchwise.

The second type of wastewater (denominated "synthetic wastewater II" or "external carbon source" - ECS), fed in the fed-batch stage, had the same composition as the "synthetic wastewater I" but without the ammonium nitrogen source $\left(\mathrm{NH}_{4} \mathrm{Cl}\right)$. In terms of COD, average concentrations of "synthetic wastewater II" were $184.8 \mathrm{mg} / \mathrm{L}$ under condition 1 and $158.7 \mathrm{mg} / \mathrm{L}$ under condition 2 . These values were considered optimal in terms of removal efficiencies and were determined after testing different ECS concentrations during the assays, i.e., varying the $\mathrm{C} / \mathrm{N}$ ratio.

\section{Experimental Setup}

The experimental setup (shown in Figure 1) consisted of an acrylic bioreactor with a volume of $3.7 \mathrm{~L}$ (a height of $540 \mathrm{~mm}$, an external diameter of $100 \mathrm{~mm}$ and a wall thickness of $3.5 \mathrm{~mm}$ ). For liquid circulation in the reactor a reservoir, also of acrylic, with an approximate volume of $1.0 \mathrm{~L}$ (a height of $450 \mathrm{~mm}$, an external diameter of $60 \mathrm{~mm}$ and a wall thickness of $3.5 \mathrm{~mm}$ ) was attached. The reactor was divided into three parts: bottom, top and middle. At the bottom a $50 \mathrm{~mm}$ high compartment $(0.34 \mathrm{~L})$ allowed enhanced distribution of the wastewater, preventing formation of preferential routes. At the top another $50 \mathrm{~mm}$ high region functioned as a biogas collector. The middle part of the reactor was divided into four $110 \mathrm{~mm}$ high compartments, each delimited by two 314 stainless steel screens. The reason for this division was to avoid bed compacting (immobilized biomass on polyurethane foam). The volume treated by the system (reactor and reservoir) was approximately 2,100 mL, of which $900 \mathrm{~mL}$ were in the reservoir and $1,200 \mathrm{~mL}$ in the reactor.
For measuring the circulation flow rate, a $100 \mathrm{~mL}$ measuring cylinder was connected between the reactor and the reservoir. It should be mentioned that the precision of recirculation flow rate measurement was verified by comparing the difference between the results obtained when the pipe was connected to the system (measuring cylinder - "closed" mode) and those obtained when it was disconnected and the volume was measured by means of an analytical balance ("open" mode). The difference was less than $4 \%$.

Recirculation flow was set at $20 \mathrm{~L} / \mathrm{h}(0.2 \mathrm{~cm} / \mathrm{s})$ and $14 \mathrm{~L} / \mathrm{h}(0.14 \mathrm{~cm} / \mathrm{s})$ for $50 \mathrm{mgN}^{-N_{4}}{ }_{4} / \mathrm{L}$ and 100 $\mathrm{mgN}-\mathrm{NH}_{4}{ }^{+} / \mathrm{L}$, respectively. The values were adapted from hydrodynamic studies (Camargo et al., 2005). These studies were performed with a conventional stimulus response procedure, using both "step and pulse" perturbations when the configuration was continuous flux, and "mixture time" when the configuration was batch mode. The assays were performed with no biomass in the inert support $(0.5$ $\mathrm{cm}$ polyurethane foam cubes). The liquid circulation flow rates were $5,10,15,20$ and $25 \mathrm{~L} / \mathrm{h}$ and the respective superficial velocities were $0.16,0.32$, $0.48,0.64$ and $0.80 \mathrm{~cm} / \mathrm{s}$. In the continuous mode the reactor showed a piston flow behavior. In the batch operation mode the mixing time obtained at all flow rates may be considered negligible compared to the total cycle time employed in the assays with biomass. Hence, in this case the reactor was considered "perfectly mixed".

The chamber in which the reactor was placed was maintained at $30 \pm 1{ }^{\circ} \mathrm{C}$ by a heating system composed of resistances and fans as well as a temperature sensor and controller. Twelve-hour operation cycles were used. Feeding and dewatering were performed by means of diaphragm pumps and circulation by a peristaltic pump. These pumps were switched on and off by an automated system.

Reactor feeding was batch-wise $(1.2 \mathrm{~L}$ filling the reactor) followed by fed batch-wise $(0.9 \mathrm{~L}$ filling the reservoir) when the external carbon source was added to the system. Batch feeding ("synthetic wastewater I" - SW) was through the reactor bottom and fed-batch feeding ("synthetic wastewater II" ECS) was between the second and third sections of the reactor (see Figure 1).

An orifice in the circulation reservoir cover (see Figure 1) allowed introduction of an aerator for aeration of the medium. It should be mentioned that aeration was interrupted during fed-batch feeding of the external carbon source. Other orifices distributed along the reactor bed (one in each compartment) and 
in the circulation reservoir cover allowed introduction of electrodes for measuring dissolved oxygen (DO) concentration and oxidation-reduction potential. Experimental conditions used are summarized in Table 1.

Regarding oxygen mass transfer dynamics, the interaction between air flow rate in the reservoir and the dissolved oxygen concentration at some points in the reactor (sample ports) and in the proper reservoir were measured. These assays were performed with immobilized biomass in the inert support. The results obtained indicated that the dissolved oxygen concentrations were approximately the same in both reactor and reservoir (deviation of less than $8 \%$ ). It was, therefore, decided to measure the dissolved oxygen concentration in the reservoir, as in this case manipulation of the dissolved oxygen probe was much easier.

\section{Details}

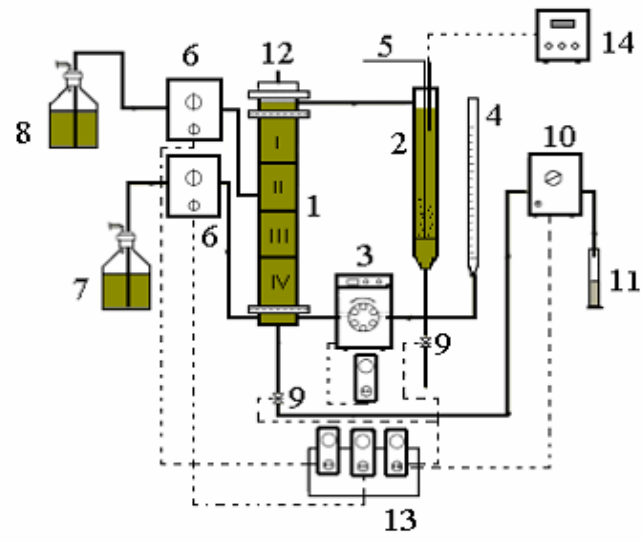

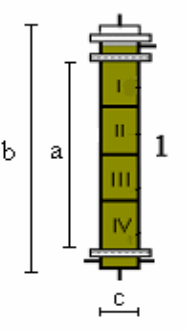

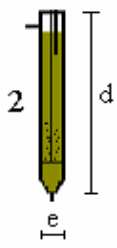

1. reactor $(\mathrm{a}=440 \mathrm{~mm} ; \mathrm{b}=540 \mathrm{~mm}$; $\mathrm{c}=100 \mathrm{~mm}$; I, II, III and IV = immobilized biomass bed);

2. circulation reservoir $(\mathrm{d}=450 \mathrm{~mm}$; $\mathrm{e}=60 \mathrm{~mm}$ );

3. circulation pump;

4. influent flow rate meter;

5. aerator;

6. feed pumps;

7. synthetic wastewater reservoir;

8. external carbon source reservoir;

9. discharge valve;

10. dewatering pump;

11. effluent outlet;

12. biogas outlet;

13. control unit;

14. dissolved oxygen concentration meter; - hydraulic lines; ----power lines.

Figure 1: Schematic representation of the sequencing batch reactor with external circulation of the liquid phase and immobilized biomass

Table 1: Summary of the experimental conditions implemented.

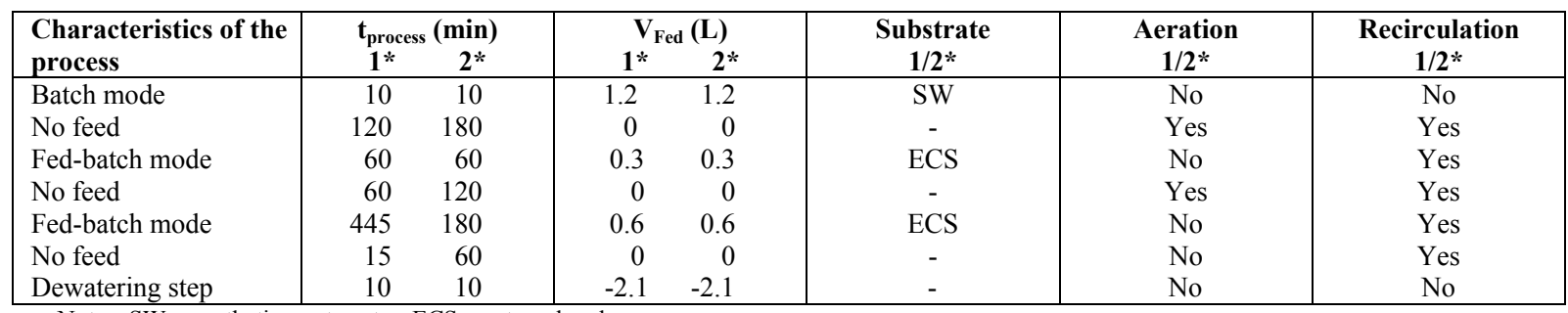

Notes: SW - synthetic wastewater; ECS - external carbon source;

$1^{*}-50 \mathrm{mgN}-\mathrm{NH}_{4}^{+} / \mathrm{L} ; 2 *-100 \mathrm{mgN}-\mathrm{NH}_{4}^{+} / \mathrm{L} ; 1 / 2 *-$ for both ammonium nitrogen concentrations.

\section{Analytical Methods}

The system was monitored in accordance with Standard Methods for the Examination of Water and Wastewater (1995) and the following were quantified: filtered and nonfiltered substrate concentration in the effluent as $\operatorname{COD}\left(\mathrm{C}_{\mathrm{ES}}, \mathrm{C}_{\mathrm{ET}}\right)-$ method $5220 \mathrm{D}$; nonvolatile and volatile total solids and total suspended solids (TS, TSS, TVS, VSS) - methods $2540 \mathrm{~B}, 2540 \mathrm{D}$ and $2540 \mathrm{E}$; bicarbonate alkalinity (BA) - method 2320 B modified by Ripley et al. (1986); total volatile acids (TVA) - method 2310 B modified by Dilallo and Albertson (1961); $\mathrm{pH}$ - method $4500-\mathrm{H}^{+} \mathrm{B}$; ammonium nitrogen $(\mathrm{N}-$ $\mathrm{NH}_{4}^{+}$) - methods $4500-\mathrm{NH}_{3} \mathrm{~B}$ and $4500-\mathrm{NH}_{3} \mathrm{C}$; organic nitrogen $(\mathrm{N}-\mathrm{Org})-\operatorname{method} 4500-\mathrm{N}_{\text {org }} \mathrm{B}$; nitrite nitrogen $\left(\mathrm{N}-\mathrm{NO}_{2}{ }^{-}\right)-\operatorname{method} 4500-\mathrm{NO}_{2}^{-} \mathrm{B}$ and nitrate nitrogen $\left(\mathrm{N}-\mathrm{NO}_{3}{ }^{-}\right)-$method $4500-\mathrm{NO}_{3}{ }^{-} \mathrm{B}$. 
For profiles, intermediate volatile acids (IVA acetic, propionic, butyric, iso-butyric, valeric, isovaleric and caproic) samples $(1 \mu \mathrm{L})$ were analyzed by gas chromatography, using a gas chromatograph HP6890 with flame ionization detector (FID) at $300^{\circ} \mathrm{C}$ and an HP-INNOWAX column (length $30 \mathrm{~m}$; a column ID of $0.25 \mathrm{~mm}$; a film thickness of 0.25 $\mu \mathrm{m}$; and a phase ratio of 250). The injector temperature was kept at $250^{\circ} \mathrm{C}$; the oven temperature was held at $100^{\circ} \mathrm{C}$ for $3 \mathrm{~min}$, after which it was heated at a rate of $5^{\circ} \mathrm{C} / \mathrm{min}$ to $180^{\circ} \mathrm{C}$ and maintained at that temperature for $5 \mathrm{~min} . \mathrm{H}_{2}(30 \mathrm{~mL} / \mathrm{min}), \mathrm{N}_{2}$ $(33 \mathrm{~mL} / \mathrm{min})$ and synthetic air $(300 \mathrm{~mL} / \mathrm{min})$ were used as carrier/flame gas, make-up gas and flame gas, respectively. The split/splitless ratio was 1:20.

Dissolved oxygen concentration (DO) and oxidation-reduction potential (ORP) were measured by specific probes.

After system stabilization the following concentration profiles were obtained during the cycle to accompany system behavior: $\mathrm{C}_{\mathrm{ES}}, \mathrm{BA}, \mathrm{TVA}, \mathrm{pH}$, IVA, N-NO ${ }_{2}^{-}, \mathrm{N}_{-} \mathrm{NO}_{3}^{-}, \mathrm{N}-\mathrm{NH}_{4}^{+}, \mathrm{N}-\mathrm{Org}, \mathrm{DO}$ and ORP. It should be mentioned that the maximum volume of wastewater that could be sampled per cycle without affecting bioreactor behavior was $10 \%$ of the total working volume $(2.1 \mathrm{~L})$. Analytical methodologies for nitrite, nitrate, ammonium nitrogen, total Kjeldahl nitrogen, $\mathrm{C}_{\mathrm{ES}}$, $\mathrm{BA}$ and TVA and IVA required, respectively, 10, 100, 50, 25, 5, 20 and $5 \mathrm{~mL}$ of each sample taken at specific times. Thus, only one sample was taken per cycle. For the entire 12-h cycle, nine cycles (or seven days) were required to analyze the different parameters. Profiles were obtained in a way so as to perturb as little as possible system behavior. Regarding nitrogen temporal profiles, because of the sample volume required for analytical methods (about $215 \mathrm{~mL}$ ), these were not performed in duplicate. Therefore, variance analyses could not be performed nor standard error bars added to the graphs.

\section{Mathematical Performance Calculation}

Reactor performance was analyzed by means of equations (1) to (15) (Canto et al., 2004, 2007):

$$
\begin{aligned}
& \%\left(\mathrm{~N}-\mathrm{NO}_{2}^{-}\right)_{\text {Produced }}= \\
& \frac{\left(\mathrm{N}-\mathrm{NO}_{2}^{-}\right)_{\mathrm{Ef}} \mathrm{V}_{\mathrm{Ef}}-\left(\mathrm{N}-\mathrm{NO}_{2}^{-}\right)_{\mathrm{B}} \mathrm{V}_{\mathrm{B}}}{\left(\mathrm{N}-\mathrm{NH}_{4}^{+}\right)_{\mathrm{B}} \mathrm{V}_{\mathrm{B}}} 100
\end{aligned}
$$

$$
\begin{aligned}
& \%\left(\mathrm{~N}-\mathrm{NO}_{3}^{-}\right)_{\text {Produced }}= \\
& \frac{\left(\mathrm{N}-\mathrm{NO}_{3}^{-}\right)_{\mathrm{Ef}} \mathrm{V}_{\mathrm{Ef}}-\left(\mathrm{N}-\mathrm{NO}_{3}^{-}\right)_{\mathrm{B}} \mathrm{V}_{\mathrm{B}}}{\left(\mathrm{N}-\mathrm{NH}_{4}^{+}\right)_{\mathrm{B}} \mathrm{V}_{\mathrm{B}}} 100 \\
& \%\left(\mathrm{~N}-\mathrm{NH}_{4}^{+}\right)_{\text {Removed }}= \\
& \frac{\left(\mathrm{N}-\mathrm{NH}_{4}^{+}\right)_{\mathrm{B}} \mathrm{V}_{\mathrm{B}}-\left(\mathrm{N}-\mathrm{NH}_{4}^{+}\right)_{\mathrm{Ef}} \mathrm{V}_{\mathrm{Ef}}}{\left(\mathrm{N}-\mathrm{NH}_{4}^{+}\right)_{\mathrm{B}} \mathrm{V}_{\mathrm{B}}} 100 \\
& \%(\mathrm{~N}-\mathrm{Org})_{\text {Removed }}= \\
& \frac{(\mathrm{N}-\text { Org })_{\mathrm{B}} \mathrm{V}_{\mathrm{B}}-(\mathrm{N}-\mathrm{Org})_{\mathrm{Ef}} \mathrm{V}_{\mathrm{Ef}}}{(\mathrm{N}-\text { Org })_{\mathrm{B}} \mathrm{V}_{\mathrm{B}}} 100 \\
& \frac{(\mathrm{N}-\text { Total })_{\mathrm{B}} \mathrm{V}_{\mathrm{B}}-(\mathrm{N}-\mathrm{Total})_{\mathrm{Ef}} \mathrm{V}_{\mathrm{Ef}}}{(\mathrm{N}-\mathrm{Total})_{\mathrm{B}} \mathrm{V}_{\mathrm{B}}} 100 \\
& \frac{(\mathrm{N}-\mathrm{Total})_{\text {Removed }}=}{(\mathrm{N}}
\end{aligned}
$$

VNLR $=$

$\mathrm{n} \frac{\left(\mathrm{N}-\mathrm{NH}_{4}^{+}\right)_{\mathrm{B}} \mathrm{V}_{\mathrm{B}}-\left(\mathrm{N}-\mathrm{NH}_{4}^{+}\right)_{\mathrm{Ef}} \mathrm{V}_{\mathrm{Ef}}}{\mathrm{V}_{\mathrm{R}}}$

$\mathrm{SNLR}=\frac{\mathrm{VNLR}}{\mathrm{C}_{\mathrm{X}}}$

$\frac{\mathrm{C}}{\mathrm{N}}=\frac{\mathrm{C}_{\mathrm{B}} \mathrm{V}_{\mathrm{B}}+\mathrm{C}_{\mathrm{FB}} \mathrm{V}_{\mathrm{FB}}}{\left(\mathrm{N}-\mathrm{NH}_{4}^{+}\right)_{\mathrm{B}} \mathrm{V}_{\mathrm{B}}}$

$\mathrm{VOL}_{\mathrm{B}}=\mathrm{n} \frac{\mathrm{C}_{\mathrm{B}} \mathrm{V}_{\mathrm{B}}}{\mathrm{V}_{\mathrm{R}}}$ 


$$
\begin{aligned}
& \mathrm{VOL}_{\mathrm{FB}}=\mathrm{n} \frac{\mathrm{C}_{\mathrm{FB}} \mathrm{V}_{\mathrm{FB}}}{\mathrm{V}_{\mathrm{R}}} \\
& \varepsilon_{\mathrm{ES}}=\frac{\left(\mathrm{C}_{\mathrm{B}} \mathrm{V}_{\mathrm{B}}+\mathrm{C}_{\mathrm{FB}} \mathrm{V}_{\mathrm{FB}}\right)-\left(\mathrm{C}_{\mathrm{ES}} \mathrm{V}_{\mathrm{Ef}}\right)}{\left(\mathrm{C}_{\mathrm{B}} \mathrm{V}_{\mathrm{B}}+\mathrm{C}_{\mathrm{FB}} \mathrm{V}_{\mathrm{FB}}\right)} \\
& \varepsilon_{\mathrm{ET}}=\frac{\left(\mathrm{C}_{\mathrm{B}} \mathrm{V}_{\mathrm{B}}+\mathrm{C}_{\mathrm{FB}} \mathrm{V}_{\mathrm{FB}}\right)-\left(\mathrm{C}_{\mathrm{ET}} \mathrm{V}_{\mathrm{Ef}}\right)}{\left(\mathrm{C}_{\mathrm{B}} \mathrm{V}_{\mathrm{B}}+\mathrm{C}_{\mathrm{FB}} \mathrm{V}_{\mathrm{FB}}\right)}
\end{aligned}
$$

\section{RESULTS AND DISCUSSIONS}

Tables 2 and 3 and Figures 2 and 3 contain the monitoring results obtained when the system was operated under conditions $1\left(50 \mathrm{mgN}-\mathrm{NH}_{4}{ }^{+} / \mathrm{L}\right)$ and 2 $\left(100 \mathrm{mgN}^{-\mathrm{NH}_{4}}{ }^{+} / \mathrm{L}\right)$.

The profiles for the cycle, which were obtained as soon as the system became stable, are shown in Figures 4 to 6 . In Table 2 the number of data used to calculate the average values of each variable is given in brackets. It should be mentioned that only values obtained during reactor stability were used to this end, resulting in average values with low standard deviations. In the figures, numbers 1 and 2 refer to conditions 1 and 2, respectively.

Regarding the average values obtained in all assays, after immobilization the bioparticles had 1.8 $\pm 0.1 \mathrm{gTVS} /$ gfoam and $2.1 \pm 0.1 \mathrm{gTS} /$ gfoam and total volatile solids in the reactor of approximately $32 \mathrm{gTVS} / \mathrm{L}$ (considering $2.1 \mathrm{~L}$ of medium inside the

\begin{tabular}{|c|c|c|c|c|}
\hline \multirow[b]{2}{*}{ Parameters } & \multicolumn{2}{|c|}{ Condition 1} & \multicolumn{2}{|c|}{ Condition 2} \\
\hline & Influent & Effluent & Influent & Effluent \\
\hline$\overline{C_{B}(m g / L)}$ & $127.9 \pm 16.7(6)$ & - & $126.6 \pm 10.1(6)$ & - \\
\hline $\mathrm{C}_{\mathrm{FB}}(\mathrm{mg} / \mathrm{L})$ & $184.8 \pm 19.7(6)$ & - & $158.7 \pm 9.4(6)$ & - \\
\hline $\mathrm{C}_{\mathrm{ES}}(\mathrm{mg} / \mathrm{L})$ & - & $22.3 \pm 8.1(6)$ & - & $20.9 \pm 5.5(8)$ \\
\hline $\mathrm{C}_{\mathrm{ET}}(\mathrm{mg} / \mathrm{L})$ & - & $26.8 \pm 8.2(6)$ & - & $25.1 \pm 5.8(6)$ \\
\hline$\varepsilon_{\mathrm{ES}}(\%)$ & - & $85.2 \pm 3.6(6)$ & - & $85.1 \pm 4.4(8)$ \\
\hline$\varepsilon_{\mathrm{ET}}(\%)$ & - & $82.1 \pm 3.7(6)$ & - & $81.9 \pm 4.1(6)$ \\
\hline $\mathrm{VOL}_{\mathrm{B}}(\mathrm{mgCOD} / \mathrm{L} \cdot \mathrm{d})$ & 146.2 & - & 144.7 & - \\
\hline $\mathrm{VOL}_{\mathrm{FB}}(\mathrm{mgCOD} / \mathrm{L} \cdot \mathrm{d})$ & 158.5 & - & 136.0 & - \\
\hline BA I Batch & $306.8 \pm 10.5(5)$ & & $591.7 \pm 9.6(6)$ & \\
\hline$\left.\left(\mathrm{mgCaCO}_{3} / \mathrm{L}\right)\right\}$ Fed-batch & $307.4 \pm 15.2(5)$ & $182.7 \pm 11.5(6)$ & $537.2 \pm 9.5(6)$ & $280.9 \pm 13.2(6)$ \\
\hline TVA Batch & $26.6 \pm 9.1(5)$ & $21.3 \pm 7.0(6)$ & $30.3 \pm 9.0(6)$ & $27.9 \pm 4.2(6)$ \\
\hline$(\mathrm{mgHAc} / \mathrm{L})\}$ Fed-batch & $22.3 \pm 7.4(5)$ & & $28.9 \pm 6.8(6)$ & \\
\hline & $8.5 \pm 0.2(5)$ & $7.5 \pm 0.1(6)$ & $8.6 \pm 0.1(6)$ & $7.7 \pm 0.1(6)$ \\
\hline $\mathrm{V}_{\mathrm{Ef}}(\mathrm{L})$ & - & $2.1 \pm 0.01(6)$ & - & $2.1 \pm 0.02(6)$ \\
\hline VSS (mg/L) & $10.0(1)$ & $22.0(1)$ & $13.2(1)$ & $20.1(1)$ \\
\hline $\mathrm{N}-\mathrm{NO}_{2}^{-}(\mathrm{mg} / \mathrm{L})$ & $0.0(1)$ & $0.07 \pm 0.01(6)$ & $0.0(1)$ & $0.17 \pm 0.03(7)$ \\
\hline $\mathrm{N}^{-\mathrm{NO}_{3}}{ }^{-}(\mathrm{mg} / \mathrm{L})$ & $0.0(1)$ & $6.4 \pm 1.9(6)$ & $0.0(1)$ & $20.4 \pm 0.8(7)$ \\
\hline $\mathrm{N}-\mathrm{NH}_{4}^{+}(\mathrm{mg} / \mathrm{L})$ & $51.1 \pm 1.1(6)$ & $1.8 \pm 0.7(6)$ & $103.7 \pm 3.3(7)$ & $1.4 \pm 0.7(4)$ \\
\hline $\mathrm{N}-\mathrm{Org}(\mathrm{mg} / \mathrm{L})$ & $4.2 \pm 0.2(6)$ & $0.5 \pm 0.2(6)$ & $11.7 \pm 0.7(7)$ & $0.0(4)$ \\
\hline
\end{tabular}
reactor).

Table 2: Average values of the monitored parameters

\begin{tabular}{|c|c|c|}
\hline Parameter & $50{\mathrm{mgN}-\mathrm{NH}_{4}}^{+} / \mathrm{L}$ & $100 \mathrm{mgN}^{-\mathrm{NH}_{4}} / / \mathrm{L}$ \\
\hline$\%\left({\mathrm{~N}-\mathrm{NO}_{2}}^{-}\right)_{\text {Produced }}$ & 0.2 & 0.3 \\
\hline$\%\left(\mathrm{~N}^{-\mathrm{NO}_{3}}\right)_{\text {Produced }}$ & 21.9 & 34.4 \\
\hline$\%\left(\mathrm{~N}-\mathrm{NH}_{4}^{+}\right)_{\text {Removed }}$ & 93.8 & 97.6 \\
\hline$\%(\mathrm{~N}-\mathrm{Org})_{\text {Removed }}$ & 79.2 & 100.0 \\
\hline$\%(\mathrm{~N}-\mathrm{Total})_{\text {Removed }}$ & 72.2 & 66.7 \\
\hline $\mathrm{BA} / \mathrm{N}-\mathrm{NH}_{4}^{+}\left(\mathrm{mgCaCO}_{3} / \mathrm{mgN}^{-\mathrm{NH}_{4}}{ }_{4}^{+}\right)$ & 4.5 & 5.0 \\
\hline $\mathrm{C} / \mathrm{N}$ & 5.2 & 2.4 \\
\hline VNLF $\left(\mathrm{mgN}_{-} \mathrm{NH}_{4}^{+} / \mathrm{L} . \mathrm{d}\right)$ & 58.4 & 118.5 \\
\hline SNLF $\left(\mathrm{mgN}^{-\mathrm{NH}_{4}}{ }_{4}^{+} / \mathrm{gTVS} . \mathrm{d}\right)$ & 1.8 & 3.7 \\
\hline $\operatorname{VNLR}\left(\mathrm{mgN} \mathrm{NH}_{4}^{+} / \mathrm{L} . \mathrm{d}\right)$ & 54.8 & 115.7 \\
\hline SNLR $\left(\mathrm{mgN}^{-\mathrm{NH}_{4}}{ }_{4}^{+} / \mathrm{gTVS} . \mathrm{d}\right)$ & 1.7 & 3.6 \\
\hline
\end{tabular}

Note: Numbers in brackets refer to the number of data used to calculate averages.

Table 3: Performance parameters of the process

Note: $\mathrm{C}_{\mathrm{X}}=32 \mathrm{gTVS} / \mathrm{L}$ and $\mathrm{C}^{\prime}{ }_{\mathrm{X}}=1.8 \pm 0.1 \mathrm{gTVS} /$ gfoam 


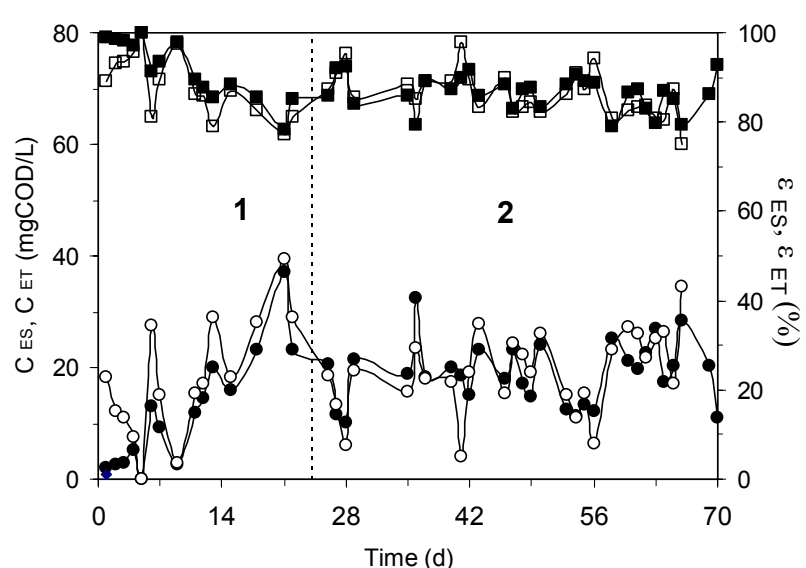

(a)

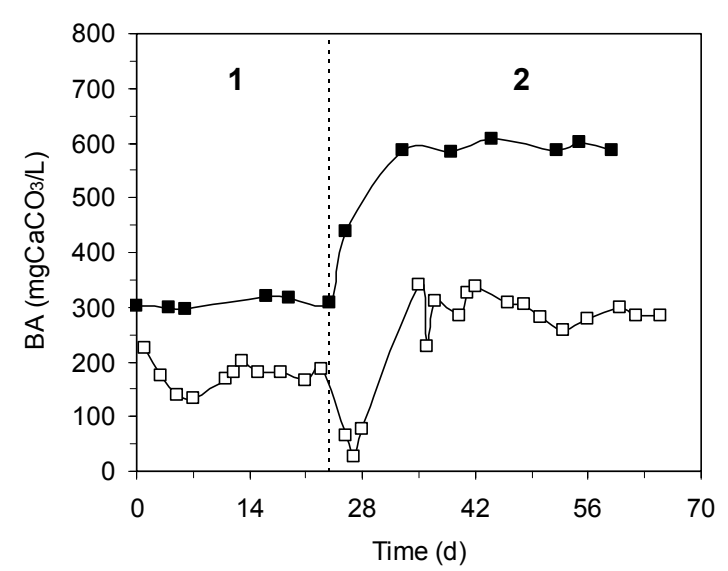

(b)

Figure 2: (a) Organic matter concentration of the filtered effluent $\mathrm{C}_{\mathrm{ES}}(\bullet)$ and of the nonfiltered effluent $\mathrm{C}_{\mathrm{ET}}(\mathrm{\circ})$, and efficiency of organic matter removal from the filtered effluent $\varepsilon_{\mathrm{ES}}(\boldsymbol{\bullet})$ and from the nonfiltered effluent $\varepsilon_{\mathrm{ET}}$ ( $\square$ ); (b) bicarbonate alkalinity (BA) of the influent ( $\left.\mathbf{}\right)$ and of the effluent (口) $\left(1: 50 \mathrm{mgN}-\mathrm{NH}_{4}{ }^{+} / \mathrm{L} ; 2: 100{\mathrm{mgN}-\mathrm{NH}_{4}}^{+} / \mathrm{L}\right)$.

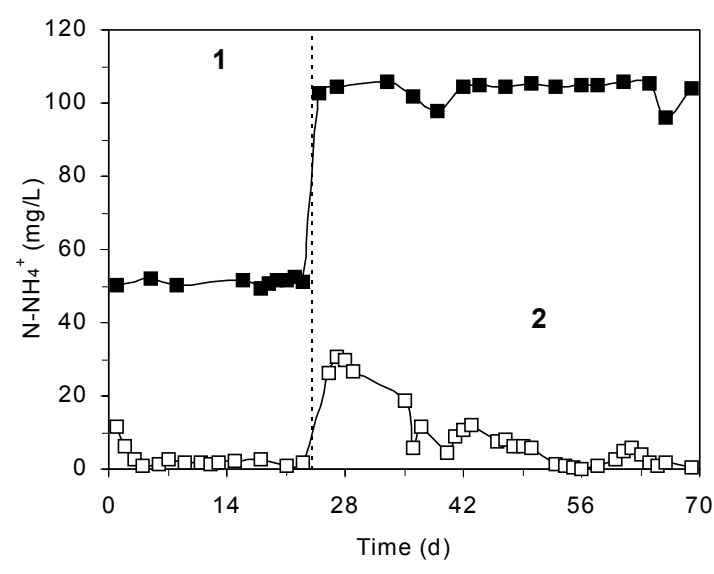

(a)

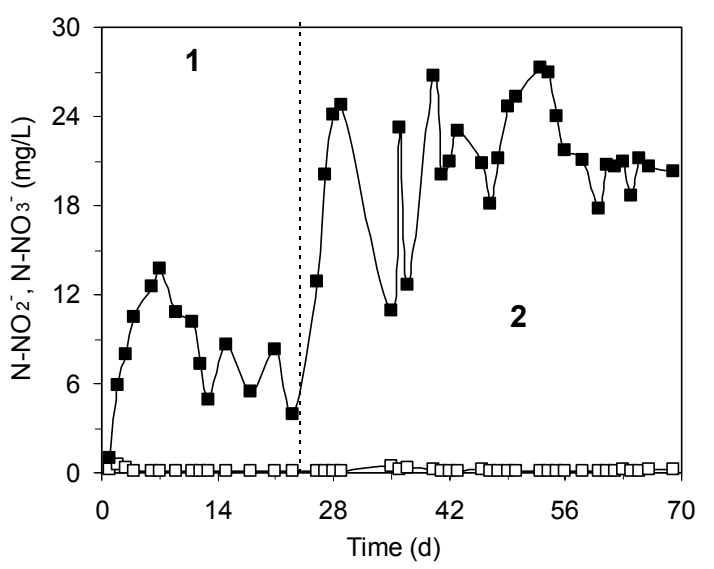

(b)

Figure 3: (a) Influent (匹) and effluent ( $\square$ ) ammonium nitrogen concentrations $\left(\mathrm{N}_{-}-\mathrm{NH}_{4}{ }^{+}\right.$);

(b) Effluent concentration of nitrite $-\mathrm{N}_{-} \mathrm{NO}_{2}{ }^{-}(\square)$ and nitrate $-\mathrm{N}-\mathrm{NO}_{3}{ }^{-}$

(匹) (1: $\left.50 \mathrm{mgN}-\mathrm{NH}_{4}^{+} / \mathrm{L} ; 2: 100{\mathrm{mgN}-\mathrm{NH}_{4}}^{+} / \mathrm{L}\right)$.

\section{Condition 1: $50 \mathrm{mgN}-\mathrm{NH}_{4}^{+} / \mathrm{L}$}

In Figure 2(a) and Table 2 it can be observed that the organic matter concentration (filtered and nonfiltered samples) was less than $40 \mathrm{mgCOD} / \mathrm{L}$ during the monitoring period and the efficiency of average organic matter removal exceeded $80 \%$. This shows that the system managed to reduce the concentration of organic matter in the batch $(1.2 \mathrm{~L}$ containing $127.7 \pm 16.7 \mathrm{mgCOD} / \mathrm{L})$ as well as in the fed-batch operation $(0.9 \mathrm{~L}$ containing $184.8 \pm 19.7$ $\mathrm{mgCOD} / \mathrm{L})$.
According to Pambrun et al., 2004, denitrification rate depends on the carbon and energy sources used and on the $\mathrm{C} / \mathrm{N}$ ratio. Low $\mathrm{C} / \mathrm{N}$ ratios may cause nitrite accumulation (Mohseni-Bandpi and Elliot, 1998), while the dissimilative reduction to ammonium may occur at high $\mathrm{C} / \mathrm{N}$ ratios (Gejlsbjerg et al., 1998) and hinder the denitrification process. Thus, during the monitoring period the organic matter concentration of synthetic wastewater II ECS (and, consequently, the $\mathrm{C} / \mathrm{N}$ ratio) was varied in order to find the optimum operational conditions, i.e., those that would result in the highest efficiency 
of total nitrogen removal. The optimum ECS concentration during the fed-batch operation was $184.8 \pm 19.7 \mathrm{mgCOD} / \mathrm{L}$ (average value obtained during the stability period of the system), resulting in a $\mathrm{C} / \mathrm{N}$ ratio of 5.2 .

Moreover, the COD values obtained for the nonfiltered influent samples $(26.8 \pm 8.2 \mathrm{mgCOD} / \mathrm{L})$ were very similar to those obtained for the filtered ones $(22.3 \pm 8.1 \mathrm{mgCOD} / \mathrm{L})$, indicating good solids retention even at low organic matter concentrations. These results open up the possibility of using the system as a COD refinement stage.

For effluent bicarbonate alkalinity, alkalinity was consumed during the cycle, as shown in Table 2 . However, influent alkalinity was sufficient to maintain the system buffered throughout the cycle, which is confirmed by the effluent $\mathrm{pH}(7.5 \pm 0.1$, on average). In Figure 2(b) it can be seen that $\mathrm{BA}_{\mathrm{Ef}}$ varied between 133 and $226 \mathrm{mgCaCO}_{3} / \mathrm{L}$, remaining around $182.7 \pm 11.5 \mathrm{mgCaCO}_{3} / \mathrm{L}$ up to the end of the experiment (stabilization period). Influent and effluent total volatile acids concentrations (measured by titration) varied during the assay, but the maximum values did not exceed $30 \mathrm{mgHAc} / \mathrm{L}$ (Table 2). This indicates that the system needs a "stock" of influent alkalinity to maintain stability, even when volatile acids production is not significant. It should be pointed out that both wastewaters (SW and ECS) used in the assays supplied alkalinity to the system, as shown in Table 2.

Theoretically, for every oxidized $\mathrm{N}-\mathrm{NH}_{4}^{+}$ molecule, two alkalinity molecules are consumed and for every reduced $\mathrm{N}-\mathrm{NO}_{3}{ }^{-}$molecule, only one is formed (Fujii et al., 1996). During the monitoring period, the average value was $4.5 \mathrm{mgCaCO}_{3} / \mathrm{mgN}$ $\mathrm{NH}_{4}{ }^{+}$, below the theoretical value (7.1 $\mathrm{mgCaCO}_{3} / \mathrm{mgN}-\mathrm{NH}_{4}{ }^{+}$) reported by $\mathrm{Kim}$ and Hao (2001). These authors obtained a $\mathrm{BA} / \mathrm{N}-\mathrm{NH}_{4}{ }^{+}$ratio of $8.5 \mathrm{mgCaCO} / \mathrm{mgN}_{3} \mathrm{NH}_{4}{ }^{+}$using a continuous-flow alternating aerobic-anoxic system, in which the conditions required for aerobic nitrification and anoxic denitrification are created. This value likely depends on the particularities of each system, which define the process direction.

Concentrations of ammonium nitrogen, nitrite and nitrate quantified during the experiment are shown in Figures 3(a) and 3(b). It can be seen that from day 3 of the assay influent $\mathrm{N}_{-} \mathrm{NH}_{4}^{+}$ concentrations remained below $3.0 \mathrm{mg} / \mathrm{L}$, resulting in an efficiency of ammonium nitrogen removal above $90 \%\left(51.1 \pm 1.1 \mathrm{mgN}-\mathrm{NH}_{4}^{+} / \mathrm{L}\right.$ in the influent, Table 2). Nitrite concentrations (Figure 3(b)) remained below $0.6 \mathrm{mgN}-\mathrm{NO}_{2}{ }^{-} / \mathrm{L}$ during the assay, whereas nitrate concentrations increased gradually during the first week and stabilized at around $6.4 \pm 1.9$ $\mathrm{mgN}-\mathrm{NO}_{3}{ }^{-} / \mathrm{L}$ until the end of the monitoring period. These results confirm the efficiency of the nitrification process, indicating that the ammonium nitrogen oxidizing bacteria as well as the nitrite oxidizing ones encountered favorable environmental conditions for the development of their metabolic functions.

The ammonification process (conversion of organic nitrogen to ammonium nitrogen) was also shown to be effective. In Table 3 it can be seen that efficiency of organic nitrogen removal from influent was $79.7 \%$, resulting in only $0.5 \pm 0.2 \mathrm{mgN}-\mathrm{Org} / \mathrm{L}$ in the effluent.

In Table 2 it is shown that during the stabilization period average effluent concentrations were $0.07,6.4$, 1.8 and $0.5 \mathrm{mg} / \mathrm{L}$ for nitrite, nitrate, ammonium and organic nitrogen, respectively. Efficiencies of total and ammonium nitrogen removal were found to be 72.2 and $93.8 \%$, respectively, and the removal rate was 54.8 mgN-NH ${ }_{4}^{+} /$L.d, i.e., $1.7{\mathrm{mgN}-\mathrm{NH}_{4}}^{+} / \mathrm{gTVS} \mathrm{d}$ (Table 3). Additionally, only $0.3 \%$ nitrite and about $21.9 \%$ of the nitrate produced remained in the system. These results corroborate the advantages of the SBBR with liquidphase circulation in the post-treatment of liquid effluents containing ammonium nitrogen by conventional nitrification/denitrification processes and show the relations between influent ammonium nitrogen concentration, operational conditions and removal efficiencies.

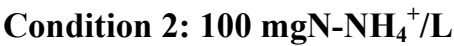

Under condition 2, the influent organic matter concentration in the batch operation, i.e., synthetic wastewater I concentration, was maintained approximately the same as that observed under condition 1 (Table 2). The concentration of external carbon source in the fed-batch operation was varied (between 90 and $240 \mathrm{mgCOD} / \mathrm{L}$ ) during the assay to obtain the concentration at which nitrogen removal was maximal. The best value found was $158.7 \pm 9.4$ $\mathrm{mgCOD} / \mathrm{L}$, a value lower than that of condition 1 , despite the twice-as-high ammonium concentration in the influent (from 50 to $100 \mathrm{mgN}^{-N_{4}}{ }_{4}^{+} / \mathrm{L}$ ).

Theoretically on doubling the influent ammonium nitrogen load the concentration of organic matter fed during the denitrification stage (fed-batch operation) should be higher, based on the condition 1 optimized $\mathrm{C} / \mathrm{N}$ ratio. However, the increase in organic matter was seen to cause a probable dissimilative reduction from nitrate to ammonium nitrogen, which was minimized when the concentration of organic matter in the fed-batch operation was reduced. As shown in 
Figure 3(a), there was an accumulation of about 30 mgN-NH${ }_{4}^{+} / \mathrm{L}$ at the beginning of the experiment when ECS concentration was approximately $200 \mathrm{mgCOD} / \mathrm{L}$, a value slightly higher than that used under condition 1 . This concentration was gradually reduced and the optimum value was $158.7 \pm 9.4 \mathrm{mgCOD} / \mathrm{L}$ (stabilization period), resulting in a $\mathrm{C} / \mathrm{N}$ ratio of 2.4 (Tables 2 and 3). This behavior gives rise to doubts about whether the $\mathrm{C} / \mathrm{N}$ ratio can be considered constant with a varying ammonium load. This issue, including optimization of system performance by varying total cycle length as well as feed and/or aeration periods, should therefore be better investigated.

In Table 2 it is shown that alkalinity was consumed during the cycle, as also observed under condition 1. In Figure 2(b) it can be seen that at the beginning of the experiment, when alkalinity was about $450 \mathrm{mgCaCO}_{3} / \mathrm{L}$ in synthetic wastewaters I and II, $\mathrm{BA}_{\mathrm{Ef}}$ attained values on the order of 25 $\mathrm{mgCaCO}_{3} / \mathrm{L}$ and $\mathrm{pH}$ of 6.9 , indicating the need to increase influent alkalinity. This behavior was caused by increased formation of nitrate when influent ammonium nitrogen was doubled (Figures 3(a) and 3(b)). Hence, $\mathrm{NaHCO}_{3}$ concentration was twice that under condition 1, resulting in 591.7 \pm 9.6 $\mathrm{mgCaCO}_{3} / \mathrm{L}$ in wastewater $\mathrm{I}$, and $537.2 \pm 9.5$ $\mathrm{mgCaCO}_{3} / \mathrm{L}$ in wastewater II (Table 2). Under these conditions effluent $\mathrm{pH}$ was on average $7.7 \pm 0.1$, showing that influent alkalinity was sufficient to maintain the medium buffered throughout the cycle.

Analysis of the two conditions studied showed that variation in bicarbonate alkalinity between influent (considering batch and fed-batch feed) and effluent was 261.2 and $603.6 \quad \mathrm{mgCaCO}_{3} / \mathrm{L}$, respectively, indicating that a higher than proportional increase occurred. This information is useful for future applications of this system in treating actual wastewaters (objective of this work), which often have variable concentrations.

Influent and effluent total volatile acids concentrations (measured by titration) also varied, but the maximum values of both did not exceed 41 mgHAc/L during the assay and the average effluent concentration was $27.9 \pm 4.2 \mathrm{mgHAc} / \mathrm{L}$ (Table 2).

The value obtained for $\mathrm{BA} / \mathrm{N}-\mathrm{NH}_{4}^{+}$ratio was $5.0 \mathrm{mgCaCO}_{3} / \mathrm{mgN}-\mathrm{NH}_{4}{ }^{+}$in the monitoring period. This value was also below the theoretical value of $7.1 \mathrm{mgCaCO}{ }_{3} / \mathrm{mgN}^{-N_{H}}{ }_{4}^{+}$described by $\mathrm{Kim}$ and Hao (2001). As previously mentioned, this value likely depends on the particularities of each system, which define process direction.

The increase in influent ammonium load from $58.4{\mathrm{mgN}-\mathrm{NH}_{4}}^{+} / \mathrm{L} . \mathrm{d}\left(1.8 \mathrm{mgN}-\mathrm{NH}_{4}{ }^{+} / \mathrm{gTVS} . \mathrm{d}\right)$ to 118
mgN-NH${ }_{4}^{+} /$L.d (3.7 mgN-NH ${ }_{4}^{+} /$gTVS.d) obviously resulted in higher nitrite and nitrate concentrations during the cycle. The reduction in influent ammonium and the increasing rise in nitrate concentration are shown in Figures 3(a) and 3(b). Nitrite levels were very low $\left(<0.5 \mathrm{mgN}^{-\mathrm{NO}_{2}}{ }^{-} / \mathrm{L}\right)$ during the experiment, indicating that the nitration stage (oxidation of the nitrite formed to nitrate) was very quick and effective and the microorganisms involved in the process encountered favorable environmental conditions for the development of their metabolic functions. It is quite likely that the increase in ammonium load resulted in an increase in concentration and/or metabolic activity of the nitrifying population.

It should be mentioned that under condition 1 nitrate concentration was around $6.4 \mathrm{mg} / \mathrm{L}$, resulting in a total nitrogen removal of $72.2 \%$. Under Condition 2 the residual nitrate concentration was thrice as high, even after having reduced the liquid superficial velocity from $0.2(20 \mathrm{~L} / \mathrm{h})$ to $0.14 \mathrm{~cm} / \mathrm{s}$ $(14 \mathrm{~L} / \mathrm{h})$ to increase the contact time between nitrate and the denitrifying microorganisms (Tables 2 and 3 ). It is quite likely that the increase in cycle length (and, consequently, the increase in denitrifying period) and/or the redistribution of aeration and no aeration favor activation of the denitrifying biomass metabolism. This nitrate at higher concentration (relative to that under condition 1) is reduced to nitrogen gas and higher efficiency of nitrogen removal is attained.

Despite this influent nitrate accumulation, the percentage of total nitrogen removed was close to that seen under condition 1, i.e., about $66.7 \%$ of total influent nitrogen was removed at a rate of $115.7 \mathrm{mgN}$ $\mathrm{NH}_{4}{ }^{+} /$L.d (3.6 $\mathrm{mgN}-\mathrm{NH}_{4}{ }^{+} /$gTVS.d) (Table 3). The ammonification process (conversion of organic nitrogen to ammonium nitrogen) was also shown to be very effective. Efficiency of organic nitrogen removal from influent was $100 \%$, as shown in Table 3. In short, the proposed system maintained efficiency, even after doubling the applied ammonium loading. The relations between influent ammonium nitrogen concentration, operational conditions and consequent removal efficiencies were shown.

\section{Profiles During a Cycle}

The behavior of the monitored variables under both conditions during a cycle is shown in Figures 4 to 6 , which may provide more insight into the kind of biotransformation occurring in these sequencing processes. 
The organic matter concentration profiles are shown in Figure 4(a). Quick consumption can be seen during the first hour of the cycle, probably by the facultative heterotrophic microorganisms, since during the first two hours the system was aerated to favor the nitrification process. After this short period

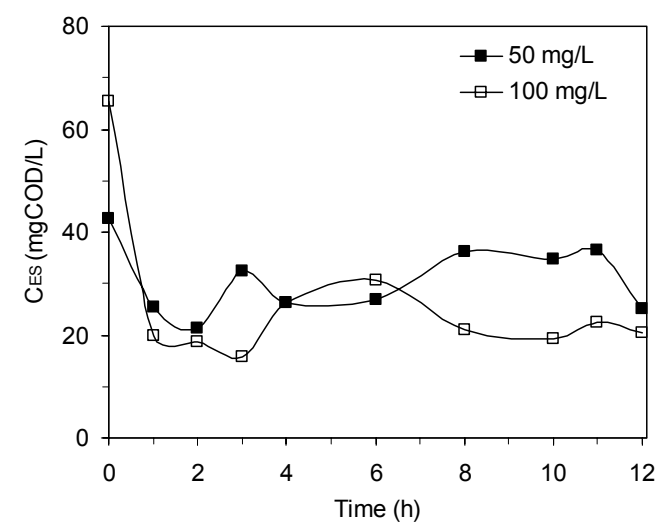

(a) the concentration of organic matter remained approximately constant, despite the operational conditions (aeration or fed-batch feeding). The average COD values obtained up to the end of the cycle were $29.9 \pm 5.7$ and $21.8 \pm 4.7 \mathrm{mgCOD} / \mathrm{L}$ under conditions 1 and 2, respectively.

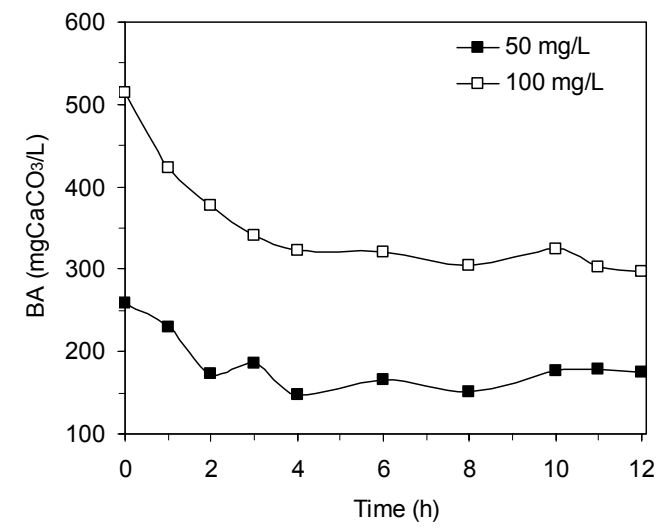

(b)

Figure 4: Effluent profiles for (a) organic matter concentration $\left(\mathrm{C}_{\mathrm{ES}}\right)$ and (b) bicarbonate alkalinity $(\mathrm{BA})$.

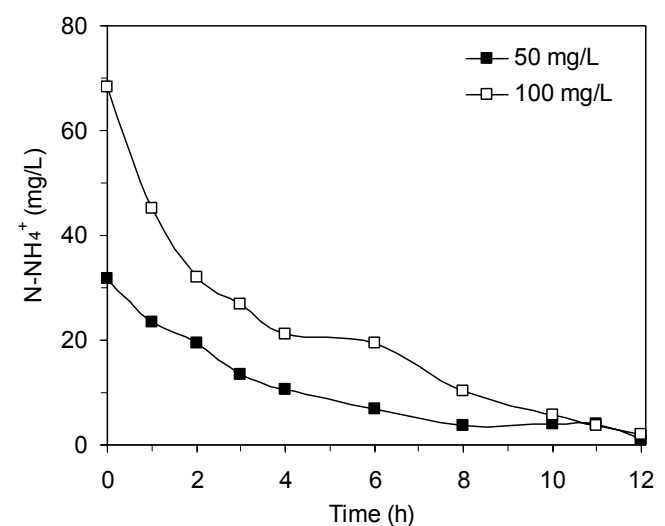

(a)

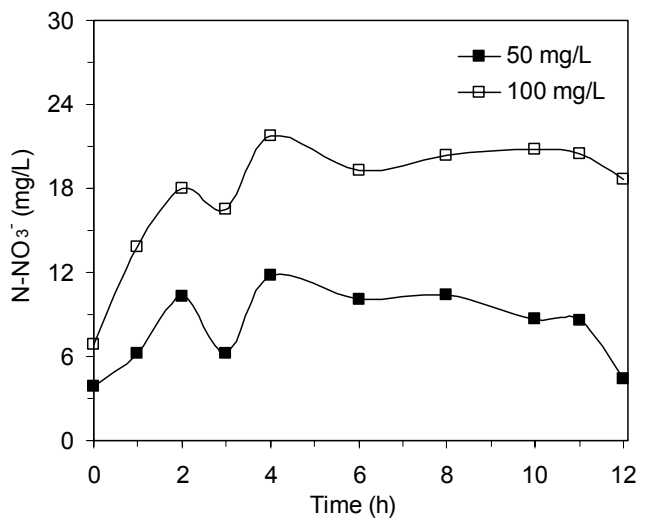

(c)

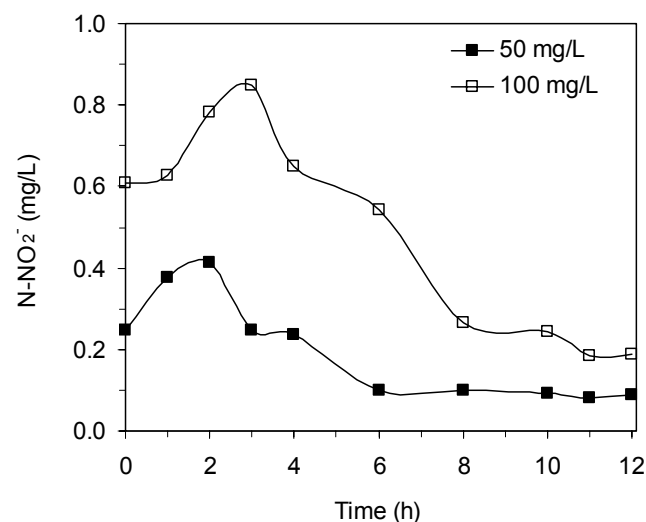

(b)

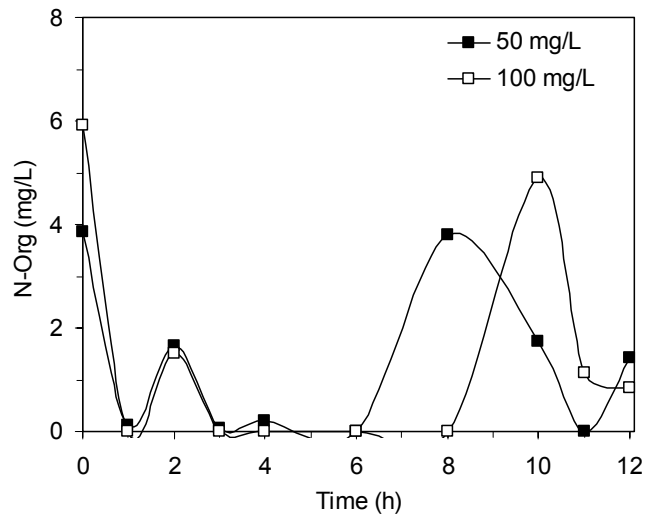

(d)

Figure 5: Effluent concentration profiles of (a) ammonium $\left(\mathrm{N}^{-\mathrm{NH}_{4}}{ }^{+}\right)$, (b) nitrite $\left(\mathrm{N}^{-\mathrm{NO}_{2}}{ }^{-}\right)$, (c) nitrate $\left({\mathrm{N}-\mathrm{NO}_{3}}^{-}\right)$and (d) organic ( $\left.\mathrm{N}-\mathrm{Org}\right)$ nitrogen. 


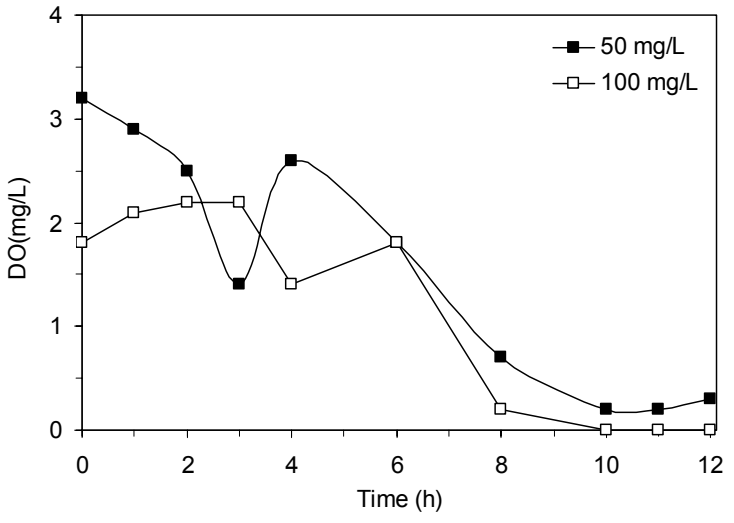

(a)

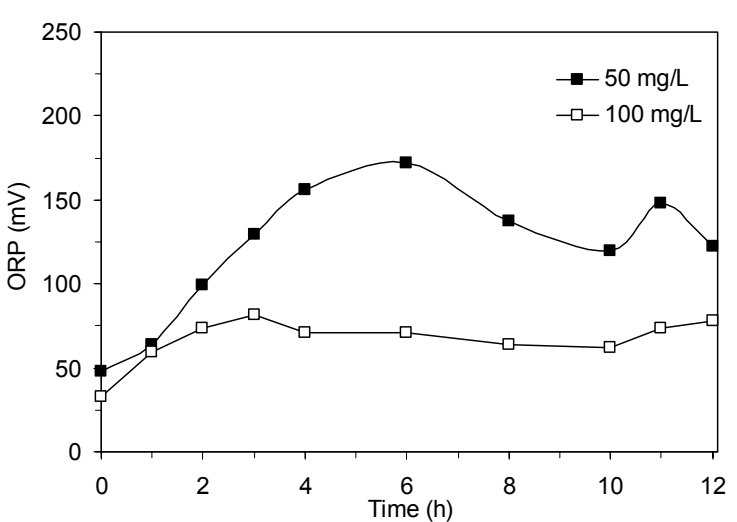

(b)

Figure 6: Profiles for (a) dissolved oxygen concentrations (DO) and (b) oxidation-reduction potential (ORP).

It should be mentioned that the composition of the external carbon source in terms of carbohydrates, proteins and lipids was similar to that of the influent containing the ammonium nitrogen source. The advantages of this are (a) reduced operational costs, since no synthetic organic compounds have to be purchased for use in the denitrification step and (b) reduction in volume of wastewater to be treated during the organic carbon matter removal stage. In an actual plant, the external carbon source might be supplied by any kind of domestic wastewater from industrial (refectory and bathrooms) as well as residential activities.

The bicarbonate alkalinity profile for condition 1 $\left(50 \mathrm{mgN}^{-\mathrm{NH}_{4}}{ }^{+} / \mathrm{L}\right)$ showed high consumption up to the fourth hour of the cycle (about $110 \mathrm{mgCaCO}_{3} / \mathrm{L}$ ), when maximum nitrification was attained (Figures 4(b) and 5(a) to 5(c)). Afterwards there was slight accumulation of alkalinity in the system (26.1 $\left.\mathrm{mgCaCO}_{3} / \mathrm{L}\right)$, maintaining on average $169.4 \pm 11.1$ $\mathrm{mgCaCO}_{3} / \mathrm{L}$ until the end of the cycle.

As previously mentioned, for every oxidized N$\mathrm{NH}_{4}^{+}$molecule, two alkaline molecules are consumed and for every reduced $\mathrm{N}_{-} \mathrm{NO}_{3}{ }^{-}$molecule, only one is formed (Fujii et al., 1996). Since this behavior was not observed, due to low accumulation of alkalinity during the denitrification stage, buffer maintenance during the cycle was guaranteed by fedbatch feeding of the ECS, as this was buffered with $\mathrm{NaHCO}_{3}(500 \mathrm{mg} / \mathrm{L})$. It should be mentioned that, despite intense nitrification during the first four hours of the cycle, ammonium nitrogen was gradually oxidized until the end of the cycle. Obviously, produced and/or ECS added alkalinity were consumed during the denitrification process.
Under condition 2 a higher consumption occurred up to the eighth hour (about $210 \mathrm{mgCaCO}_{3} / \mathrm{L}$ ). After this period, alkalinity remained stable until the end of the cycle at $307.6 \pm 14.2 \mathrm{mgCaCO}_{3} / \mathrm{L}$. Under condition 2 buffering had to be increased due to a higher consumption in the nitrifying step, increasing the influent $\mathrm{NaHCO}_{3}$ concentration from 500 (condition 1) to $1000 \mathrm{mg} / \mathrm{L}$. As under condition 1, ammonium nitrogen was also gradually oxidized until the end of the cycle with consumption of produced ECS, thus adding alkalinity during the fedbatch operation (Figures 4(b) and 5(a)).

Profiles for total volatile acids (titration method) showed that concentrations varied during the whole cycle, with a maximum (at about $50 \mathrm{mgHAc} / \mathrm{L}$ ) after four hours of the cycle under both conditions studied (data not shown).

In Figure 5(a) continuous oxidation of ammonium nitrogen until the eighth hour of the cycle, independent of strategy of operation (aeration or no aeration) can be seen. At this point, when dissolved oxygen concentration attained minimum levels $(<1 \mathrm{mg} / \mathrm{L}$, Figure 6(a)), ammonium nitrogen concentration remained practically constant until the end of the cycle under both conditions studied.

Comparison of nitrite and nitrate profiles (Figures 5(b) and 5(c)) shows that under condition 1 nitrite concentration attained a peak in the second hour of the cycle (Figure 5(b)). Between the third and fourth hours, when aeration was reinitiated, no accumulation took place, despite an increase in dissolved oxygen concentration from 1.4 to $2.6 \mathrm{mg} / \mathrm{L}$ (Figure 6(a)). In this period nitrate concentration $(\mathrm{N}-$ $\mathrm{NO}_{3}{ }^{-}$) attained almost $12 \mathrm{mg} / \mathrm{L}$ and was slowly reduced until the end of the cycle (Figure 5(c)). 
Nitrite concentration stabilized at around $0.09 \mathrm{mg} / \mathrm{L}$ and nitrate concentration reached $4.4 \mathrm{mg} / \mathrm{L}$. Under condition 2 nitrite concentration attained a peak after three hours of the cycle (Figure 5(b)). From that point on it gradually dropped, even during the second aerobic phase. At the end of the cycle concentration reached $0.19 \mathrm{mg} / \mathrm{L}$. As nitrite concentration decreased, nitrate concentration increased during the cycle, attaining a maximum value of $21.8 \mathrm{mg} / \mathrm{L}$ after around four hours (Figure $5(\mathrm{c}))$. Contrary to the profile obtained under condition 1 , nitrate was not reduced during addition of external carbon source and its concentration was maintained at about $20.2 \mathrm{mg} / \mathrm{L}$ up to the end of the cycle, regardless of $\mathrm{C} / \mathrm{N}$ ratio adopted. Thus, nitrite and nitrate showed behavior typical of intermediate metabolites.

Total volatile acids concentrations, measured by titration, varied to a great extent during the cycle, under both conditions studied. However, concentrations remained at about 17.0 and 21.8 $\mathrm{mgHAc} / \mathrm{L}$ from the tenth hour up to the end of the cycle under conditions 1 and 2, respectively (data not shown). It should be mentioned that under both conditions, no intermediate volatile acids were detected by gas chromatographic analysis during the cycle. In the chromatographic analysis individual concentrations of some acids, such as acetic, propionic, iso-butyric, butyric, iso-valeric, valeric and caproic, were measured. On the other hand, formic and lactic acid are only detected by titration analysis. Certainly, concentrations of the acids that can be detected by chromatography were below detection levels and are therefore only measurable by titration.

The ORP profiles (Figure 6(b)) had positive values during the cycle in both cases. As a rule ORP is positive in aerobic zones and negative in anoxic zones. However, ORP was positive even when DO concentration was practically zero. It should be mentioned that DO and ORP values were respectively measured in the side reservoir and in the reactor. As previously mentioned, hydrodynamic studies have shown the reactor to be perfectly mixed and so these values were considered representative of the system and not of isolated points. On the other hand, the complexity of the system does not allow conclusions to be drawn on the actual conditions of the microorganisms inside the bed. The conclusion thus reached is that due to system complexity ORP could not be regarded a process control parameter, as occurs in other systems (Koch and Oldham, 1985; Caulet et al., 1998; Klapwijk et al., 1998; Zhao et al., 1999; Kim and Hao, 2001; Kishida et al., 2004).
The experimental protocol allowed understanding of the main steps of this process and can be used to establish the optimal operational conditions for maximum efficiency of nitrogen removal.

\section{CONCLUSIONS}

The reactor, which operated in sequencing batch and fed-batch mode with external liquid circulation, 12-h cycles, intermittent aeration and immobilized biomass and which used synthetic wastewater (free ammonium nitrogen) in the fed-batch mode as external carbon source for denitrification, was shown to be adequate in the post-treatment for removal of ammonium nitrogen, with high solids retention.

Efficiencies of ammonium and total nitrogen removal of 93.8 and $72.2 \%$ were obtained, respectively, when the influent fed into the system contained $50 \mathrm{mgN}-\mathrm{NH}_{4}{ }^{+} / \mathrm{L}$. The BA-to-N-NH${ }_{4}^{+}$ratio amounted to $4.7 \mathrm{mgCaCO} / \mathrm{mgN}^{-N_{4}}{ }_{4}^{+}$and residual nitrite, nitrate and organic nitrogen were $0.07,6.4$ and $0.5 \mathrm{mg} / \mathrm{L}$, respectively. On the other hand, when ammonium nitrogen concentration in the treated effluent was doubled, i.e., $100 \mathrm{mgN}-\mathrm{NH}_{4}{ }^{+} / \mathrm{L}$, residual nitrite and nitrate were 0.17 and 20.4 , respectively. It should be mentioned that residual nitrate remained unaltered at the different $\mathrm{C} / \mathrm{N}$ ratios implemented. Consequently, efficiency of total nitrogen removal was reduced to $66.7 \%$, despite an efficiency of ammonium nitrogen removal of more than $90 \%$.

Reactor monitoring was complemented by profile runs of the main process variables (COD, ammonium nitrogen, nitrite, nitrate, bicarbonate alkalinity, dissolved oxygen and ORP), which allows understanding of system behavior in terms of existing relations between the operational variables (aeration and feeding periods as well as external carbon source concentration, i.e., $\mathrm{C} / \mathrm{N}$ ratio) and enables system optimization. This experimental protocol, along with the results, shows the potentiality of the proposed system for removing ammonium nitrogen from liquid effluents and future scale-up application.

\section{ACKNOWLEDGMENTS}

This study was supported by the Fundação de Amparo à Pesquisa do Estado de São Paulo, FAPESP, process numbers 01/05489-0 and 02/07504-0. We gratefully acknowledge the contribution of Dr. Baltus C. Bonse in the revision of this paper. 


\section{NOMENCLATURE}

\section{Symbols}

$\mathrm{BA} / \mathrm{N}^{-\mathrm{NH}_{4}}{ }^{+}$Bicarbonate alkalinity consumed per ammonium nitrogen removed from the system

$\mathrm{BA}_{\mathrm{B}} \quad$ Bicarbonate alkalinity in batch mode

$\mathrm{BA}_{\mathrm{Ef}} \quad$ Bicarbonate alkalinity in the effluent

$\mathrm{BA}_{\mathrm{FB}} \quad$ Bicarbonate alkalinity in fed-batch mode

$\mathrm{C} / \mathrm{N} \quad$ Ratio of the influent organic matter to the ammonium nitrogen

$\mathrm{C}_{\mathrm{B}} \quad$ Influent organic matter concentration in batch mode

$\mathrm{C}_{\mathrm{ES}} \quad$ Filtered organic matte concentration in the effluent

$\mathrm{C}_{\mathrm{ET}} \quad$ Nonfiltered organic matter concentration in the effluent

$\mathrm{C}_{\mathrm{FB}}$ Influent organic matter concentration in fed-batch mode

$\mathrm{C}_{\mathrm{X}} \quad$ Biomass concentration in the reactor per total volume of liquid

$\mathrm{C}^{\prime} \mathrm{x} \quad$ Biomass concentration in the reactor per mass of polyurethane foam

DO Dissolved oxygen concentration

IVA Intermediate volatile acids

$\mathrm{n} \quad$ Number of cycles a day

$\left(\mathrm{N}-\mathrm{NO}_{2}{ }^{-}\right)_{\mathrm{B}} \quad$ Concentration of nitrite nitrogen in batch mode

$\left(\mathrm{N}-\mathrm{NO}_{2}{ }^{-}\right)_{\mathrm{Ef}} \quad$ Concentration of nitrite nitrogen in the effluent

$\%\left(\mathrm{~N}-\mathrm{NO}_{2}\right) \quad$ Percentage of nitrite

Produced nitrogen produced by the system

$\left(\mathrm{N}-\mathrm{NO}_{3}{ }^{-}\right)_{\mathrm{B}} \quad$ Concentration of nitrate nitrogen in batch mode

$\left(\mathrm{N}-\mathrm{NO}_{3}{ }^{-}\right)_{\mathrm{Ef}}$ Concentration of nitrate nitrogen in the effluent

$\%\left(\mathrm{~N}-\mathrm{NO}_{3}{ }^{-}\right)$Percentage of nitrate

Produced nitrogen produced by the system

$\left(\mathrm{N}-\mathrm{NH}_{4}^{+}\right)_{\mathrm{B}} \quad$ Concentration of ammonium nitrogen in batch mode

$\left(\mathrm{N}-\mathrm{NH}_{4}{ }^{+}\right)_{\mathrm{Ef}}$ Concentration of ammonium nitrogen in the effluent

$\mathrm{mgCaCO}_{3} / \mathrm{L}$

$\mathrm{mgCaCO}_{3} / \mathrm{L}$

$\mathrm{mgCaCO}_{3} / \mathrm{L}$

$\mathrm{mgCaCO}_{3} / \mathrm{L}$

$\operatorname{mgCOD} / \mathrm{L}$

$\operatorname{mgCOD} / \mathrm{L}$ Percentage of ammonium

$\begin{array}{ll}\%\left(\mathrm{~N}-\mathrm{NH}_{4}{ }^{+}\right) & \text {nemoved } \\ \text { Ritrogen removed from the }\end{array}$ system

$(\mathrm{N}-\mathrm{Org})_{\mathrm{B}} \quad$ Concentration of organic nitrogen in batch mode

$(\mathrm{N}-\mathrm{Org})_{\mathrm{Ef}}$ Concentration of organic nitrogen in the effluent

$\%(\mathrm{~N}-\mathrm{Org}) \quad$ Percentage of organic

Removed nitrogen removed from the system

$(\mathrm{N}-$ Total $) \quad\left(\mathrm{N}-\mathrm{NO}_{2}{ }^{-}\right)+\left(\mathrm{N}^{-\mathrm{NO}_{3}}{ }^{-}\right)+(\mathrm{N}-\quad \mathrm{mg} / \mathrm{L}$ $\left.\mathrm{NH}_{4}^{+}\right)+(\mathrm{N}-\mathrm{Org})$

$(\mathrm{N}-\text { Total })_{\mathrm{B}}$ Concentration of total nitrogen in batch mode

$(\mathrm{N}-\mathrm{Total})_{\mathrm{Ef}}$ Concentration of total nitrogen in the effluent

$\%(\mathrm{~N}-$ Total) Percentage of total nitrogen

Removed removed from the system

ORP Oxidation-reduction potential

SNLF Specific ammonium nitrogen loading fed into the system

SNLR Specific ammonium nitrogen loading removed from the system

$t_{\text {process }} \quad$ Synthetic wastewater and external carbon source feed time in each cycle step

-foam Total solids Total suspended solids Total volatile acids

Total volatile solids Synthetic wastewater (containing ammonium nitrogen) volume fed in batch mode

$\mathrm{mg} / \mathrm{L}$

$(-) \quad V_{B}$

$\mathrm{mg} / \mathrm{L}$

$\begin{array}{ll} & \mathrm{V}_{\mathrm{Ef}} \\ \% & \mathrm{~V}_{\mathrm{FB}}\end{array}$

Dewatered volume

External carbon source

$0.9 \mathrm{~L}$ volume fed in fed-batch mode

$\mathrm{mg} / \mathrm{L} \quad \mathrm{V}_{\mathrm{FED}} \quad$ Volume fed into the system in each cycle step

$\mathrm{mg} / \mathrm{L} \quad \mathrm{VNLF} \quad$ Volumetric ammonium $\mathrm{mgN}^{-\mathrm{NH}_{4}}{ }^{+}$ nitrogen loading fed into the system

VNLR

Volumetric ammonium $\mathrm{mgN}-$ nitrogen loading removed $\quad \mathrm{NH}_{4}^{+} / \mathrm{L} . \mathrm{d}$ from the system

$\mathrm{mg} / \mathrm{L}$

$\%$

$\mathrm{mg} / \mathrm{L}$

$\mathrm{mg} / \mathrm{L}$

$\%$

$\mathrm{mg} / \mathrm{L}$

$\mathrm{mg} / \mathrm{L}$

$\%$

$\mathrm{mV}$

$\operatorname{mgN}-\mathrm{NH}_{4}^{+} /$

gTVS.d

$\operatorname{mgN}-\mathrm{NH}_{4}^{+} /$

gTVS.d)

$\min$

$\mathrm{mg} / \mathrm{L}$

$\mathrm{mg} / \mathrm{L}$

$\mathrm{mgHAc} / \mathrm{L}$

$\mathrm{mg} / \mathrm{L}$

$1.2 \mathrm{~L}$

\section{L}

$\mathrm{mg} / \mathrm{L}$ 
$\mathrm{VOL}_{\mathrm{B}} \quad$ Volumetric organic loading in batch mode

$\mathrm{VOL}_{\mathrm{FB}} \quad$ Volumetric organic loading in fed-batch mode

$V_{R} \quad$ Reaction volume, equal to dewatered volume

VSS Volatile suspended solids

$\mathrm{mg} / \mathrm{L}$

\section{Greek Letters}

$\begin{array}{ll}\varepsilon_{\mathrm{ES}} & \begin{array}{l}\text { Efficiency of filtered } \\ \text { organic matter removal }\end{array} \\ \varepsilon_{\mathrm{ET}} & \begin{array}{l}\text { Efficiency of nonfiltered } \\ \text { organic matter removal }\end{array}\end{array}$

\section{Abbreviations}

COD Chemical oxygen demand

ECS External carbon source

FID Flame ionization detector

SBBR Sequencing batch biofilm reactor

SBR Sequencing batch reactor

SW Synthetic wastewater

UASB Up-flow anaerobic sludge blanket

\section{REFERENCES}

Aulenta, F., Dionisi, D., Majone, M., Parisi, A., Ramadori, R. and Tandoi, V., Effect of Periodic Feeding in Sequencing Batch Reactor on Substrate Uptake and Storage Rates by a Pure Culture of Amaricocus kaplicensis. Water Research, 37, 2764-2772 (2003).

Bilanovic, D., Battistoni, P., Cecchi, F., Pavan, P. and Mata-Alvarez, J., Denitrification Under High Nitrate Concentration and Alternating Anoxic Condition. Water Research, 33(15), 3311-3320 (1999).

Camargo E. F. M., Canto C.S.A., Ratusznei S.M., Rodrigues J. A. D., Zaiat M. and Borzani W., Hydrodynamic Analysis of an Anaerobic Sequencing Batch Biofilm Reactor with LiquidPhase External Circulation. Journal of Science and Technology of the Americas INTERCIÊNCIA, 30(4), 188-194 (2005).

Canto, C. S. A., Rodrigues, J. A. D., Ratusznei, S. M., Zaiat, M. and Foresti, E., Feasibility of Nitrification/Denitrification in a Sequential Batch Biofilm Reactor with Liquid Circulation Applied to a Post-Treated Effluent. 1st International
Meeting on Environmental Biotechnology and Engineering, Mexico City, Mexico, (CD-ROM) (2004).

Canto, C. S. A., Rodrigues, J. A. D., Ratusznei, S.M., Zaiat, M. and Foresti, E., Feasibility of Nitrification/Denitrification in a Sequencing Batch Biofilm Reactor with Liquid Circulation Applied to Post-Treatment. Bioresource Technology, 99(3), 644-654 (2008).

Caulet, P., Bujon, B., Philippe, J.P., Lefreve, F. and Audic, J.M., Upgrading of Wastewater Treatment Plants for Nitrogen Removal: Industrial Application of an Automated Aeration Management Based on ORP Evolution Analysis. Water Science and Technology, 37(9), 41-47 (1998).

Dillalo, R. and Albertson, O.E., Volatile acids by direct titration. Journal of Water Pollution Control Federation, 3, 356-365 (1961).

Fujii, S., Theoretical Analysis on Nitrogen Removal of the Step-Feed Anoxic-Oxic Activated Sludge Process and its Application for the Optimal Operation. Water Science and Technology, 34(12), 459-466 (1996).

Gejlsbjerg, B., Frette, L. and Westermann, P., Dynamics of $\mathrm{N}_{2} \mathrm{O}$ Production from Activated Sludge. Water Research, 32(7), 2113-2121 (1998).

Kim, H. and Hao, O. J., pH and Oxidation-Reduction Potential Control Strategy for Optimization of Nitrogen Removal in an Alternating AerobicAnoxic System. Water Environmental Research, 73, 95-102 (2001).

Kishida, N., Kim, J. H., Chen, M., Tsuneda, S., Sasaki, H. and Sudo, R., Automatic Control Strategy for Biological Nitrogen Removal of Low $\mathrm{C} / \mathrm{N}$ Wastewater in a Sequencing Batch Reactor. 3rd IWA International Specialised Conference on Sequencing Batch Reactor Technology, Noosa, Queensland, Australia, (CD-ROM) (2004).

Klapwijk, A., Brouwer, E., Vrolijk, E. and Kujawa, K. Control of Intermittently Aerated Nitrogen Removal Plants by Detection Endpoints of Nitrification and Denitrification Using Respirometry Only. Water Research, 32(5), 17001703 (1998).

Koch, F. A. and Oldham, W. K., OxidationReduction Potential - a Tool for Monitoring, Control and Optimization of Biological Nutrient Removal Systems. Water Science and Technology, 17, 259-281 (1985).

Linlin, H., Jianlong, W., Hua, W.X. and Yi, Q., Study on Performance Characteristics of SBR Under Limited Dissolved Oxygen. Process Biochemistry, 40, 293-296 (2005). 
Louzeiro, N. R., Mavinic, D. S., Oldham, W.K., Meisen, A. and Gardner, I.S., Methanol-Induced Biological Nutrient Removal Kinetics in a Full-Scale Sequencing Batch Reactor. Water Research, 36, 2721-2732 (2002).

Metcalf \& Eddy, Inc. Wastewater Engineering Treatment, Disposal and Reuse. 4th Edition. McGraw-Hill Book Co., Singapore, (2003).

Mohseni-Bandpi, A. and Elliot, D.J., Groundwater Denitrification with Alternative Carbon Source. Water Science and Technology, 38(6), 237-243 (1998).

Obaja, D., Macé, S. and Mata-Alvarez, J., Biological Nutrient Removal by a Sequencing Batch Reactor (SBR) Using an Internal Organic Carbon Source in Digested Piggery Wastewater. Bioresource Technology, 96, 7-14 (2005).

Pambrun, V., Paul, E. and Spérandio, M., Treatment of Nitrogen and Phosphorus in Highly Concentrated Effluent in SBR and SBBR processes. Water Science and Technology, 50(6), 269-276 (2004).

Peng, Y., Chen, Y., Peng, C., Liu, M., Wang, S., Song, $\mathrm{X}$. and Cui, Y., Nitrite Accumulation by Aeration Controlled in Sequencing Batch Reactors Treating Domestic Wastewater. 3rd IWA International Specialised Conference on
Sequencing Batch Reactor Technology, Noosa, Queensland, Australia, (CD-ROM) (2004).

Ripley, L. E., Boyle, W. C. and Converse, J. C., Improved Alkalimetric Monitoring for Anaerobic Digestion of High-Strength Wastes. Journal of Water Pollution Control Federation, 58: 406411(1986).

Standard Methods for the Examination of Water and Wastewater, 19th ed, American Public Health Association / American Water Works Association / Water Environment Federation, Washington, D.C., USA (1995).

Souza, J. T. and Foresti, E., Domestic Sewage Treatment in the Up-Flow Anaerobic Sludge Blanket - Sequencing Batch Reactor System. Water Science and Tecnology, 33(3), 73-84 (1996).

Zaiat M., Cabral A. K. A. and Foresti E., HorizontalFlow Anaerobic Immobilized Sludge Reactor for Wastewater Treatment: Conception and Performance Evaluation. Brazilian Journal of Chemical Engineering, 11, 33-42 (1994).

Zhao, H. W., Mavinic, D. S., Oldham, W. K. and Koch, F. A., Controlling Factors for Simultaneous Nitrification and Denitrification in a Two-Stage Intermittent Aeration Process Treating Domestic Sewage. Water Research, 33, 961-970 (1999). 